\title{
11
}

\section{BETWEEN MISSION AND INTERESTS}

\author{
The evolving role of the Catholic Church \\ in the Czech Republic and Poland
}

\author{
Joanna Kulska
}

\section{Introduction}

Among the diverse actors present in the discourse on interest groups, religious groups have been rarely, albeit increasingly, discussed. In Europe, this refers in particular to historical majority Churches, which in different parts of the continent contributed significantly to the development of both social and political institutions shaping contemporary European states. The Catholic Church is one such influential actor, which has attracted much attention in research on Western Europe (Werner, 2001; Minkenberg, 2003; Fink, 2008) but received less attention in CEE (Stan \& Turcescu, 2011; Ramet, 2014; Grzymała-Busse, 2015). The chapter aims at the comparative analysis of the evolving role, goals, and strategies applied by the Catholic Church in Poland and the Czech Republic, taking into consideration the significantly different position of the religious factor in social-political contexts in both countries. Following the argument that religion is a major structural factor characterizing societies and likely to change little over time (Fink, 2008, p. 1646), I argue that the political entanglement of particular national churches in the post-communist context needs to be viewed as a relatively dynamically evolving phenomenon. According to this perspective, national church hierarchies adjust their strategies to altering sociopolitical reality, depending on their accessibility to the political arena. This process can lead to backing off from active engagement in the political sphere as in the Czech Republic or moving from an agenda-setting strategy to a veto-player function in Poland (see Fink, 2009). In the Polish case, the veto-player strategy may be based not on the mobilization potential of the religious electorate but on doctrinal premises, as I illustrate on the abortion issue. Due to the growing role of the identity factor in policy-making, it is an option for political elites to instrumentalize the Church, especially in countries where religion has been an important tool in shaping loyalty toward the state. 


\section{Theorizing the Catholic Church as a political actor}

There are two basic understandings of the Catholic Church, a more institutional and a more communal understanding. According to the first, the religious community forms the organizational-institutional unity represented by its leaders who hold their posts and act uniformly as such. According to the second, the Catholic Church is the community of the faithful who want to follow the values and norms of the religion and not perform their religious affiliation as a uniform institutionalized subject (Böckenförde et al., 1994, p. 92).

In its own understanding, the Church is not an interest group. This perception is the result of the aspirational character of the Catholic social doctrine based on three main principles, subsidiarity, solidarity, and the common good (Höffner, 1992, pp. 29-41). According to this approach, if the Church's institutions function based on those directives, they do not conflict with state institutions. They also do not aim at achieving particular goals gained with harm to the community. The crucial argument used in this regard is the postulate of independence toward the state and the postulate of coordination (Papieska Rada Iustitia et Pax, 2005, pp. 276-278).

Political science analyses of the Church's political-institutional specifics are much more complex, because the Catholic Church is an institution that does not follow clear-cut categorizations. The Church is perceived as a denominational organization, institutionalized religious community, interest group, political actor, or political subject (Kowalczyk, 2014, p. 126). Looking at the Catholic Church as an interest group, three main approaches exist. First, the Church is one of many interest groups and regardless of its religious mission, it also performs social functions and participates in the public debate on not only sociocultural but also political issues. Second, it is a specific interest group as the social engagement of the Church complements its religious mission. Third, the Church is not an interest group as its social engagement is only an additional aspect of its activities (Dylus, 2005, pp. 99-101).

Almond et al. (2000) categorize churches, along with the army, bureaucracy, and corporations, as institutional interest groups which, while articulating their own interests, also carry out other political and social functions. In this sense, they carry out an evangelizing mission but simultaneously may have a significant influence on political processes (Kowalczyk, 2014, p. 128). Following this approach, it needs to be stressed again that there are various understandings of the Catholic Church. Since the Church as a whole includes both Catholic laity and leadership, it can be looked upon from two different perspectives: the perspective of the membership group and the perspective of the institutional group representing a hierarchical institution acting similarly to a corporation (Camissa \& Manuel, 2016, p. 4).

A useful categorization of this atypical interest group was proposed by Warner, who perceives the Catholic Church as an institution aiming at accessing goods from the political and economic system of the state just like other interest groups 
but, at the same time, having some specific features which no other interest group possesses. As such, the Catholic Church is the authoritative supranational institution to which all "national branches" are supposed to refer. Also, typical of only this particular interest group is that it functions based on the claim of universality of moral authority and is treated as the ultimate moral authority by its followers (Warner, 2001, pp. 7-8). As an interest group not following unequivocal categorizations, the Catholic Church can also be regarded as unique due to its number of followers. Contrary to interest groups usually representing "minority groups", the Catholic Church represents the majority of the society, at least in Poland among other countries (Graniszewski, 2015, p. 118).

The Church's range of concerns reaches beyond those of other interest groups. The Church was not created for the purpose of lobbying governments to obtain resources for its leadership and members or battle various institutional enemies (Warner, 2001, p. 7). Gaining influence over political authorities is not an aim in itself for the church. This influence is meant to secure the institutional stability of its structures and improve its effectiveness in performing social and religious functions (Zuba, 2010, p. 117). Yet, while Churches undoubtedly embody the sacred and the divine, their interests and influence extend well beyond the spiritual realm to the extent that warrants exploring the aims of the Church exceeding its mission. As Anna Grzymała-Busse shows in her seminal book: "Many countries are 'nations under God', where churches are powerful political actors, shaping policy and transforming lives in the process" (Grzymała-Busse, 2015, p. 2).

When achieving their goals, Churches rarely stand alone and united against the state. In reality, they create alliances with other political actors and other churches (Enyedi, 2003, p. 227). They also do not stick to one universal strategy as they have to take into consideration national specifics and sometimes long lists of factors shaping their national political standing. As a result, they can influence particular political systems either directly or indirectly. First, they influence policy by openly declaring their convictions, contacting public officials, or organizing protests. Second, they gain institutional access, which is a far more powerful instrument than creating partisan coalitions or relying on diffuse voter demand (Grzymała-Busse, 2015, p. 332).

Looking at the place and role of the Catholic Church in the political system, its relation to civil society must not be overlooked. According to many categorizations, religious organizations and bodies are subjects of the civil society sector. This approach is expressed, among others, in the official documents of the European Union (EU), which define Churches as institutions of civil society that engage citizens, especially at the local level (Szymczak, 2015, p. 52). They have functioned as such for decades in Western Europe, where processes of regulating mutual relations were initiated much earlier than in CEE. However, their relationship to civil society in the central part of the continent appears to be more complex and political. Moving away from the atheist model severely limiting the freedom of conscience and belief and organizing, often from the scratches, the mutual relations between the state and the Church were challenging in all 
possible aspects. These included the social-political sphere but also political attempts to strengthen the political position of dominating churches including the Catholic Church. This not only resulted in formal legal challenges but also raised the question to what extent the Churches would or would not contribute to the processes of pluralization and building a strong, active, and independent civil society.

Although "catholic" means "universal," the Catholic Church is by no means homogenous in terms of both its formal-legal standing and social-political entanglement. The Catholic Church is a transnational organization with a centralized hierarchical structure to which the representatives of national Catholic Churches are responsible. Since the doctrine or institutional structure, being the same, do not determine the specifics of national churches, any differences that may exist are the result of the national settings that override their commonalities (Kratochvíl, 2009, p. 126). Thus, by theoretically following the same universal pattern regulating the mutual relations between state and Church based on the principle of separation of religious and world orders, national contexts of delimitating between the given, concrete state and Catholic Church differ significantly. Also, the issue of the internal fractions occurring at the highest state- level organizations such as the National Conferences of Bishops should be taken into consideration. Finally, the Church in the institutional sense has been significantly diversified not only at the national but also at the local diocese and parish level where different political-religious settings exist ${ }^{1}$ (Cammisa \& Manuel, 2016, p. 4). Hence, the universality of the Church should be analyzed as the general principle and point of departure for interpreting the doctrine and the scope of activities but not in terms of specific relations with the political power determined by national and local factors.

\section{Poland: the Catholic Church as an agenda-setter and veto-player}

Weakened by the communist regime in a material sense due to the nationalization of the majority of the Church's property, the Catholic Church in Poland entered the transformation period as a strong and influential mediator between the old and the new political elites. Since the beginning of the 1990s, the Church mobilized with a new sense of mission based on "religious truths" in order to influence political decision-making, thought, and language. A good example is the term "unborn children" that has become rooted in the public discourse. Since then, the activities of the Church have taken on a more or less political character, never abandoning the political sphere totally (Zuba, 2010, p. 116).

The foundations of the mutual relations between the state and the Church in Poland were defined within the first four years after 1989 (Gowin, 1995; Gowin, 1999). At that time, the political scene was dominated by the centrist and rightist parties that generally deemed taking into consideration the religious values and material interests of the Church as justifiable (Zuba, 2020, p. 3). These 
developments found expression at the institutional level where the bilateral bodies serving as the platforms for regular consultations between the Church and the government such as the Joint Commission of the Episcopate, the Property Commission, and the Concordat Commissions, in fact, became quasi-corporation forums for the Church to influence the government (Zuba, 2010, p. 124). Using its institutional access, the Church not only proposed bills at this stage but also intervened in appointing civil servants and officials. "All sides of the political spectrum acceded to these demands for fear of destabilizing Polish democracy and newly found sovereignty" (Grzymała-Busse, 2015, p. 165).

The opposition toward the "special treatment" of the Church, even though then absent at the societal level, ${ }^{3}$ grew fast within left-liberal political circles. In the atmosphere of the "religious cold war"4 which embodied increasing criticism against the Church among society as well as anticlerical parties and media (Dudek, 2016, pp. 169-173), some important concessions toward the Church were made. They involved introducing religious education to schools as well as antiabortion regulations, which since then have been a constant topic in the political discourse accompanied by the return of Church's property and the regulations on Christian values in education and public radio and television. Civil partnerships and in vitro fertilization were added later to the list of issues influenced by the Church.

Three main political strategies were applied by the Polish Catholic Church during the first two decades of transformation. First, it acted as a political principal, which meant exerting direct influence on the political scene by supporting Catholic national parties. Second, it shaped political values which, in practice, meant supporting the establishment of Christian Democratic parties. Finally, after 2004, while formally withdrawn from political activities, the Church engaged politically by supporting the Catholic national Radio Maryja, which has been very influential in sustaining the traditional, conservative wing of Polish Catholicism. ${ }^{5}$ In the following years, both direct and indirect instruments of influence were applied (Zuba, 2010, p. 124) in the form of the official and back-channel meetings of the bishops with political decision-makers, conferences, symposia, letters, and statements directed at politicians but also activities of religious advocacy groups (Kowalczyk, 2019, pp. 95-96).

According to Grzymała-Busse (2015), the Polish Church has been the most powerful interest group and is likely to remain so due to various sociocultural and political factors. First, despite the strong criticism and growing distrust toward the Church, society is often passive and disengaged from reforming an institution, which represents a crucial element of self-identification. Although critical toward the Church's political engagement, voters do not express this criticism at the ballot box. At the same time, Polish politicians preserve the "tradition" of good relations with the Church and avoid, except for some rare cases, ${ }^{6}$ open conflict with the Church. As Poland is arguably an example of the greatest possible fusion of religious and national identities in the region, it is also one of the examples of the greatest moral authority of the Church gained in the course 
of its "stormy history." Even though this type of authority does not correspond with the popular need for engaging the Church in politics, it corresponds with the attitudes of the political elites wary of offending organized religion. Characteristic of Poland is thus the level of mutual links both between the nation and faith and between politicians and the Church's hierarchy. A system of "suprapolitical" bonds that are often stronger than the political cleavages has been created (Grzymała-Busse, 2019, pp. 23-25).

"Supra-political" bonds characterizing relations between the state and the Church have not prevented the latter from altering its strategy in posttransformation Poland. While the Church initially could have been perceived as an active agenda-setter, later it adopted a veto-player strategy, before eventually becoming a quite passive, selective "third-way seeker" on some issues. Although this last strategy definitely is not applied by the whole Catholic clergy and not even the whole leadership embodied by the Episcopate, it does apply to the more open and more self-critical Church's leadership meaning, among others, the primate archbishop Wojciech Polak. The lack of internal cohesion is well evidenced at the level of the Episcopate of Poland where the strong divisions between the more conservative and the more liberal wings have been observed, with the conservative one "winning the battle" in the public reception (Dylus, 2019, pp. 131-140).

Its role as agenda-setter developed when the belief in the Church's pivotal role during the communist period was politically utilized by the ruling centrist and rightist parties in the early transformation period. Later, under conditions of the decreasingly favorable social-political climate, a slow evolution toward less-direct engagement could be observed. The political strategy of the Church developed toward that of a veto-player, as displayed by ever-present issues such as abortion, civil partnership regulations, and in vitro fertilization, which were opposed by the Church even in the moderate versions proposed by Catholic politicians such as Jarosław Gowin (Dąbrowska \& Szacki, 2020, pp. 19-21). The Church expressed clear disapproval toward the legal proposals introduced at parliament, but the final outcomes were the result of different political settings: either the decisions made by state organs (the president, Constitutional Tribunal) practically applying Church's argument (abortion), or the members of parliament expressing their personal religious convictions in the legislative process (civil partnerships), or conservative political party (PiS - Prawo i Sprawiedliwoścl) Law and Justice) introducing financial restrictions from the state budget (in-vitro fertilization) (Zuba, 2020). Regarding abortion, religious interest groups such as Fundacja Pro, Instytut Ordo Iuris or Polska Federacja Ruchów Obrony Życia (Polish Federation of Movements to Defend Life) have also been increasingly influential actors (Kowalczyk, 2019).

The turn from a more active agenda-setter toward a more passive veto-player seems to have been determined by two main developments: the increasing instrumentalization of the Church by conservative parties and the increasing social criticism and distrust among the society toward the Church. ${ }^{7}$ This tendency 
became more apparent since PiS and its allies entered the political scene and openly used religious-national arguments for political purposes. The breakthrough moment may have been the dispute over the "Smoleńsk cross" 8 in 2010. While the Episcopate did not take sides in the conflict, politicians and conservative media, including the leader of PiS, Jarosław Kaczyński, openly instrumentalized the symbol of the cross to mobilize more religious supporters (Kublik et al., 2013).

Two other issues exemplify the new Church strategy of distancing itself from political engagement and embracing the "third-way seeker" option, namely the discourse on migration and the problem of nationalistic attitudes. Though often presented in public discourse as the Church's political attitude, the Church, in fact, has never officially declared anti-migrant views or support for nationalistic radicalism. By contrast, in both cases, the Church's official stance was directed against the goals of the PiS government. Since 2015, the official position of the Episcopate was to accept a limited number of migrants in the spirit of Christians' obligation to help refugees, and it has not changed since then (Modrzejewski \& Raczyński, 2019). Despite numerous calls of the Episcopate, including the primate Wojciech Polak, and the president of Polish Episcopate Conference archbishop, Stanisław Gądecki, as well as signing the official agreement on cooperation with the Community of Sant Egidio as the leader of the project of Humanitarian Corridors in Europe, the Polish government's stance on the issue has stayed the same. As to the problem of increasing radical nationalism in 2017 in the document entitled "Christian shape of patriotism," the Episcopate made a sharp distinction between the positive attitude of patriotism meaning the "love of the homeland" and the attitudes contrary to patriotism, among them "national egoism, nationalism, cultivating the sense of own superiority, closing itself against other national communities and all-human community" (Konferencja Episkopatu Polski, 2017).

The historical-demographic matrix that resulted in the political-legal positioning of the Catholic Church was one of the essential determinants shaping the Polish public sphere after 1989. The Church not only influenced the transformation process and the axiological fundaments of the political system but also contributed to legitimizing post-Solidarity elites, electoral behaviors, and the public debate. The model embarked by the Church turned out to be the one "inbetween" the political and the metapolitical, meaning both the presence in the life of the political community as a participant in the political process and carrier of values (Kowalczyk, 2019, p. 96). As such, the Church used multiple strategies, from agenda-setter to veto-player, but it also attempted to signal its own political voice even at the cost of opposing "friendly" political decision-makers.

\section{Czech Republic: the Catholic Church as a civil society actor}

Contrary to Poland, the structural weakness of the Czech Catholic Church after 1989 became a key issue in the process of regulating relations with the state and 
exerting political influence. Problems such as the lack of organizational structures at the dioceses and national level as well as lacking experience in contacts with the government bodies were visible. The essential factor influencing churchstate relations were the Church's dependence on the government in communist times, which in practical terms meant that priests and bishops received their salaries from the state budget and were thus regarded as civil servants (O'Mahony, 2003 , p. 180). From an institutional perspective, both the nonreligious perception of Hussitism and the noninstitutional reception of religion by President Masaryk were also crucial.

The Czech Catholic Church is characterized by its passiveness, especially in the social-political realm. It also aimed to renew its institutional structures based on tactics from the pre-communist era, but in general, it is only weakly involved in social consultations (Kaczmarek, 2016, p. 282). This passive approach can also be explained by the political failure to make meaningful headway in the institutionalization of civil society (Potǔček, 2000, pp. 107-121). As Joan O'Mahony (2003) noted, this failure brought with it numerous attacks on many religious organizations, not just the Catholic Church. This politics of exclusion can be perceived in the wider context of the Church's inability to impact policy-making, neither through direct linkages with the state nor by influencing political parties.

While supported by over $50 \%$ of society, including non-Catholics in the $1990 \mathrm{~s}$ (Kaczmarek, 2016, p. 247), the relatively strong social position of the Church has been significantly weakened by the political controversy over the return of Church property. In the mid-1990s, the growing strength of the political party KDU-CSL, traditionally perceived as connected to the Church, resulted in the recognition of the Catholic Church's involvement in political issues and a further decrease in trust. Declining support for the Church was also effected by statements by the head of the Catholic Church at that time, Cardinal Vlk, who became not only the face of the restitution issue but also a public critic of the current political developments, including the critics of Václav Klaus' government (1996-1997). The period of controversies and disputes lasted until 2006 when, among others, the Catholic Church softened its unfavorable view of Jan Hus. ${ }^{10}$

Since 2010, the political position of the Church has been shaped by the new primate Dominik Duka, who started his term in office by solving the dispute on the issue of the Saint Vitus Cathedral with President Klaus. The process of reaching a settlement between the Church and the government took two decades. It started in 1992 and culminated in 2012 during the intensive political debate and the passing of the bill on restitution. Primate Duka's attempts also increased the level of engagement of the Church in the social and cultural realm. An important part of his activities were current issues of Czech public life from the perspective of the Church's teachings. In the following years, the Czechs found themselves among countries expressing the lowest level of trust in the Church. ${ }^{11}$

According to Jan Vánĕ, the fact that Roman Catholics represent the largest religious group in the Czech Republic, with 10\% of society declaring affiliation 
to the Catholic Church, can be approached from two perspectives. On the one hand, this makes the Church a powerful institution

formally disposing of $10 \%$ of the population on which it can rely in political and religious disputes with the non-religious majority. On the other hand, various research projects have shown that in the eyes of the broad public, the Church hardly exercises influence that would match its cultural and historical significance.

(Vánĕ, 2013, pp. 115-116)

In the legal sense, its weak position is evidenced by the lack of a binding agreement regulating its status. Signed in 2002 by the Apostolic Nuncio Archbishop Erwin Josef Ender and Minister of Foreign Affairs Cyril Svoboda, it was never ratified by parliament.

While, in Poland, the Catholic Church has held a monopolistic position in the sociopolitical structure, the Czech Catholic Church is perceived as one of many interest groups and, as such, has never been subject to a more detailed analysis in political science (Kaczmarek, 2016, p. 230). Society expects less and less from the Church except for its social services. As a result, the Church's strategy has been to turn its attention away from the state. Instead, it has formed alliances and strived "to draw the public's attention to civil society and to be active in the public space, also emphasizing the need to work for the community in its broadest possible sense" (Vánĕ, 2013, pp. 116-117). In the practical sense, this approach has been pursued, along with other entities, by Caritas, which runs 1,340 facilities and serves 145,000 registered clients (Czech Bishops Conference, 2019).

The Czech Catholic Church has focused on family, old age, sickness, and pastoral activism aimed at young people. Even though its agenda has been defined, the Church has been unsuccessful in creating tools enabling it to become involved in political decision-making. With decreasing interest and support from political parties, it withdrew from active political involvement and focused more on economic and social problems. Thus, the current public agenda is formulated outside official Church structures. The leading role is thus played by individuals and driven by their personal effort to formulate current areas of interest. In practice, this means paying a lot of attention to the laity which the Czech Catholic Church recognizes as an integral part of the Church (Vánĕ, 2013, pp. 113-120).

\section{Catholic Church in Poland and the Czech Republic: between national religion and civic religion}

Poland and the Czech Republic are considered extremely different cases in terms of constructing national identity and legitimizing the contemporary position of the Catholic Church, both socially and politically. In the Czech Republic, a non-denominational civic religion ${ }^{12}$ was developed, "laic Christianity" as described by the prominent philosopher and anti-communist activist Jan Patočka. 
Both the Polish Church and political authorities have "politicized" and instrumentalized religion based on the concept of "regaining" national culture and national identity, with the Church at the center of the "great Polish nation". The aims of the Catholic Church are thus political and nonpolitical. It strives for both concrete short-term objectives as well as the long-term alteration of social and political values, attitudes, and behaviors. As such, independently of the same doctrinal source and organizational patterns, they constitute examples of different roles and political strategies of the Church.

In Poland, where the Catholic Church is said to constitute "the fourth branch of the government" (Ramet, 2017, p. 1), it holds a religious monopoly. In the vastly homogenous society, roughly $10 \%$ do not identify with the Catholic Church. In the highly secularized, though at the same time spiritual Czech population (Havliček, 2006, p. 331), 10\% identify as Catholics. While in Poland the Roman Catholic Church is perceived as the protector of the nation during the partition and loss of independence, in the Czech Republic it is perceived as opposing the Czech nation and associated with Habsburg rule against pro-independent ambitions of Protestant nobles. Hence, 75\% of Poles perceive a fusion of the Church and nation, while only $29 \%$ of Czechs do (Grzymała-Busse, 2015, p. 28). Poland offers examples of frequently offensive nationalism, the instrumentalization of religion, and its de-universalization (Zenderowski, 2010, p. 39). Czechs meanwhile may be considered the only example of modern national identity constructed upon laicized religious tradition (Zenderowski, 2018, p. 199).

The different political position of the Church is also visible in public discourse. Czech public discussions are rarely framed in religious terms (Kratochvíl, 2009, p. 128). In Poland, references to the heritage of Poland's Christian civilization are crucial elements of the public discourse conveyed by the government-controlled public media, especially since 2015. The essence of this strategy was the opinion expressed by the leader of the ruling party PiS, Jarosław Kaczyński, who declared in September 2019 that outside the Catholic Church in Poland there is only nihilism. ${ }^{13}$ One year earlier at Jasna Góra monastery, considered the "spiritual capital of Poland," Prime Minister Mateusz Morawiecki warned supporters of the Catholic Radio Maryja, the perceived political arm of PiS, that just like during the Swedish invasion in the XVII century "in the free Poland for the last 25 years and even today different ideological opponents have been trying to excavate under Poland, under Polishness, under our traditional values: family, patriotism, the dream of the great, magnificent Poland" (Deon, 2018).

Both in Poland and the Czech Republic, the Catholic Church influences education and social services on different scales. The Church became involved in Czech education, health care, and the army by offering religious services and psychological support, and in public television by having the right, in the capacity of a social organization, to appoint representatives to the national media board (Maćkowiak, 2020, p. 48). Since 1989, more than 100 church school institutions at all levels of education have been established or restored (Havlíček, 
2006, p. 337), including three Catholic theological faculties in Prague, Olomouc, and České Budějovice (Tretera \& Horák, 2017). Also crucial from the perspective of strengthening civic activeness, the influence and importance of church humanitarian organizations have increased with The Charity of the Roman Catholic Church ${ }^{14}$ among the most important organizations in Czechia.

The Polish Roman Catholic Church is the biggest nongovernmental organization not only in Poland but also in Europe (Zuba, 2010, p. 117). It counts over 10,000 parishes and almost 25,000 clergies (ISKK, 2020, p. 4). It also acts as the "mobilizer" in terms of social engagement. Being the largest nongovernmental organization, the Church fosters the civil engagement of otherwise passive citizens. Janusz Czapiński concludes that religious and Church organizations are the forms of organized advocacy in which a significant part of Poles engage. As he underlines, in general, Poles rather do not participate much, do not belong anywhere, and do not act, unless mainly religious and Church organizations are involved (Szymczak, 2015, p. 52). ${ }^{15}$ The Church became engaged in the educational sector and social sector by developing a broad educational and social network consisting of over 560 Catholic schools, two Catholic universities in Lublin and Cracow, and nine theological faculties. Three million beneficiaries have been offered support by the Church's institutions, not counting the help offered at the parish level. The Church has become the second provider of social services after the state (KAI, 2018). ${ }^{16}$

What both countries have in common is a model of Church-State relations based on autonomy and cooperation (German model), which recognizes the positive social role of the Church(es) and its presence in the public sphere. Meanwhile social-cultural, political, and formal-legal differences regarding the position of the Church are enormous. Two examples are the relations to the Holy See and financing of the clergy. The Czech Republic is the only CEE country without a concordat or some kind of other agreement signed with the Holy See. Following the old Habsburg pattern of Church-state relations, it also fully finances the clergy, which in Poland would be unacceptable ${ }^{17}$ due to the historical independence of the Church.

\section{Abortion: from universality to locality}

The evolution of the abortion policy in the whole post-Soviet bloc was one of the most visible examples of the Catholic Church's influence in the countries where it had played a strong political role in the pre-communist period. Prior to the collapse of communism, abortion was legal in all Soviet-bloc countries since the 1950s, including the Soviet Union, except for Romania where it was delegalized under Ceauşescu. The passing of these laws did not result from the women's movement or demands for reproductive freedom. The logic was rather of economic nature and was motivated by the state's need to increase women's participation in the labor force (Githens, 1996, p. 55). 
Regarding abortion in Poland, the Church has acted as both a trendsetter and veto-player depending on the phase of the process. In particular in the early transformation period, even before the semi-free elections in Poland when the first official talks were held between the Church and the communist government, it acted as a trendsetter. The first bill banning abortion, which later became the basic point of reference to all next proposals, was drafted by lawyers appointed by the Episcopate, finalized in the Joint Commission, and introduced in the Sejm in the last days of the communist regime in May 1989 (Grzymała-Busse, 2015, p. 171).

From the beginning, the Church framed abortion as both a fundamental matter of natural law and the condition of the survival and development of the nation. Even then, the Church declared it will defend the unborn children even if it had no allies left (Episkopat Polski, 1991, p. 23). Simultaneously, it stressed that abortion should not become a topic of public debate due to its fundamental moral character. Following this line, a strategy was adopted, aimed at preventing a referendum on the issue. This proved to be effective within the next years when the parliament attempted to pass a bill on the referendum. ${ }^{18}$ The divisions regarding abortion, which later turned into political conflict, emerged both within the political arena and at the public opinion level, making abortion one of the most important and most controversial political issues in post-transformation Poland. In the heated debate, the pro-choice camp was referred to as "communist" or even the "Eichmann-Mengele-Stalin" option, while the opposite pro-life option was named "medieval" and "clerical" (Wielowieyska, 2020).

After the more than three-year controversy, a settlement was reached in 1993. Referred to as "the Anti-Abortion Act,", and known in the public discourse as the "abortion compromise," the Act of 7 January 1993 restricted the possibility of performing abortions to just three cases: a threat to the woman's life or health; irreversible damage to the fetus; and pregnancy resulting from a prohibited act (The 1993 Act). In the following years, with leftist governments, and later a leftist president Aleksander Kwaśniewski, the Act of 7 January 1993 was not changed and is binding until now. The reform attempt, namely The Act of Amendment of the Penal Code which was passed by the parliament in 1994, was vetoed by President Lech Wałęsa the same year. Two years later, when a group of MPs proposed another liberalization of the Anti-Abortion Act, it was overruled as nonconstitutional by the Constitutional Court. Though this is impossible to prove this decision was based on religious premises, this verdict was among the most controversial in the history of the Constitutional Court (Zuba, 2020).

Abortion became a fundamental political issue again before the 2003 EU Accession Referendum, with the Church acting now more in the capacity of a (potential) veto-player. At that time, the Church pursued a significantly modified approach compared to its earlier direct engagement. It is debatable what form of political influence the Church exerted before the referendum. Some observers raise arguments that the Church offered to back accession if the abortion law was not liberalized (Grzymała-Busse, 2015, p. 176). However, the then 
leading politicians such as Leszek Miller suggest that the influence was not direct but rather a method of preventive steps undertaken by the ruling left-wing government. According to Miller, there was no "pacting" with the Church. His decision not to "go on war" with the Church, meaning not reopening the abortion issue, was not due to an agreement with the Church but mainly out of fear that the local parish priests could discourage their parishioners from participating in the EU accession referendum (Wielowieyska, 2020). Thus, the element of bottom-up negative mobilization over abortion affected the crucial political developments regarding EU accession. During the following years, internal divisions emerged within political parties such as PSL and PiS, between which opposite attitudes on the abortion issue have always been present. ${ }^{19}$

The abortion issue as one of the most important political topics of the posttransformation decades has come to bear in recent years especially in the form of civic legislative initiatives such as Stop aborcji (Stop abortion) or Zatrzymaj aborcje (Halt abortion) supported by the Church by means of public appeals and letters. Noticeable in this regard is the change of rhetoric used in the debate compared to three decades ago. The narrative is no longer that abortion is "evil," rather something that is "not ok." Arguments of scientific nature have also been increasingly used by the Church. Meanwhile, support for eugenic abortion has been decreasing according to public opinion polls (Konferencja Episkopatu Polski, 2018).

Yet, a decision by the Constitutional Tribunal issued on 22 October 2020 has again somewhat unexpectedly heated up the "cultural war" (Korolczuk, 2020). Based on a petition led by a group of PiS parliamentarians in late 2019, the Constitutional Tribunal ruled abortion unconstitutional due to heavy, uncurable, and lethal damage to the fetus. This sparked massive protests engaging various political, social, and cultural groups expressing diversified views and attitudes. In addition to reproductive rights, the groups also called for LGBT rights, the removal of religious education from school curricula, climate action, animal rights, better education, and health care, among others (Strajk Kobiet, 2020). Eventually, abortion served as the "umbrella" issue which was well visible on the often very innovative posters carried by the protesters. While for the majority of protesters the fundamental right of women to decide on abortion was the fundamental issue, for many others it was an opportunity to demonstrate their hatred for the Church (expressed also by the acts of apostasy), the government, and, often personally, Jarosław Kaczyński.

This shed light on deep internal divisions within the Polish clergy. More liberal circles of the Church, both the clergy and Catholic journalists (Przeciszewski, 2020) trying to justify the protests, avoided open confrontation and appealed for deep reflection within the Church. More conservative members spoke of "collective possession," attributing the protests to the radical, ultraleftist activities carrying out "Satan's deeds" and "persecuting the Church." The strategy of political confrontation and "using" the Church was well evidenced in the rhetoric applied by the representatives of the Episcopate, on the one hand, and the government, on the other hand. When primate Wojciech Polak appealed 
for respect for "holy places," Jarosław Kaczyński called on PiS supporters to defend the church for any price, arguing that attacks on the church should not be perceived as accidental. Soon, Jarosław Kaczyński made the argument that the parliamentary opposition has "blood on its hands" due to the rising numbers of Covid victims as an alleged sideeffect of the protests.

Contrary to Poland, the topic of abortion has not been a significant political issue in the Czech Republic. Already in the 1950s when abortion was legalized in Czechoslovakia, it was framed as a medical issue, not an ethical one, and as a way to healthier motherhood (Dudová, 2010, p. 945). Since 1989, the issue has returned periodically, also in the moral context, but the political influence of the Catholic Church has not been the determining factor. Focus has been placed more on economic issues and the necessity to build a stronger civil society. This line of reflection and teaching was expressed, in particular, in the letter "Peace and good" (Pokoj a dobro) published in 2000 in which Czech bishops critically looked at the direction of development of the country in an excessively liberal and free-market direction. As a reaction to the letter, President Václav Klaus expressed his critique toward this engagement by the Church. In an article published in "Lidové noviny" in 2001, he encouraged the Church to pay more attention to issues such as abortion or the death penalty (Kaczmarek, 2016, pp. 302-303).

In the next years, the dominating force politically engaged in the abortion issue were single representatives of the Christian-Democrat KDU-ČSL. However, neither in 2003 nor in 2008 when they proposed banning abortion was it a top political issue. At the same time, abortion has been constantly addressed by different organizations gathered under the pro-life movement organizing yearly Marches for Life. However, they do not demand a ban on abortion, as this idea is perceived as unrealistic. Instead, their main focus has been the pragmatic goal of decreasing the number of the abortions performed and organizing more sufficient care for mothers and their families.

\section{Concluding remarks}

Three decades after the transformation, the Czech Catholic Church tends to be "one of many" actors in the social-political sphere. In Poland, its status is rather "one over many" still, though decreasingly, advocating corporatist aims and strategies. This status has resulted in still existing close bonds between the Church and the state, through which both the Church and the state exploit their mutual dependence. In the Czech Republic, the lack of such dependence translates into more civil society-oriented activities in the social and charity domains and avoiding direct political participation. At the same time, the element common to both models has been the move toward more passive political engagement. In this regard, the recent involvement of the primate of the Czech Catholic Church, Dominik Duka, in controversies around political attempts to limit the freedom 
of public media has been quite puzzling. In Poland meanwhile, this passiveness has gained its own dimension. The question has been increasingly discussed in which direction the political influence of the Catholic Church will evolve in the connection to "dark side" of civil society and illiberal democracy problem. Once linked to democratic transformation, the process of pluralization and building a strong, active, and independent sphere of engaged citizens challenging the state, now some segments of civil society are turning away from those values. Instead, this illiberal civil society leans toward authoritarian power-promoting, top-down processes of building alternative organizations and movements supportive of government policies (Ekiert 2018; Ekiert, 2019). In Poland, this has already resulted in the adoption of new financing rules for NGOs and support for organizations with a more nationalist and Roman Catholic profile (Mandes, 2020, p. 112). Whether and to what extent the Church will engage itself in this strategy of the government may define not just short-term political interests but its long-term political and social standing.

\section{Notes}

1 Subsidiarity is a basic concept of Catholic theology that it is incumbent upon society to nurture basic human relationships. Thus, policies should be administered whenever possible at the level closest to the individual (Cammisa \& Manuel, 2016, p. 5).

2 The undebatable sign of the close relations between the Church and the politicians was the consent to use the name Catholic by the coalition of the conservative rightwing Catholic Electoral Action (Wyborcza Akcja Katolicka) in the election of 1991.

3 In the early transformation period, public support for the Church was $90 \%$. It dropped to under $40 \%$ by mid- 1993 .

4 The term "cold religious war" was coined by Jarosław Gowin to describe churchstate relations in 1990 (Sowiński, 2014, p. 660).

5 Radio Maryja has become a central ideological pillar for consolidating Polish national-catholic ideology (Krzemiński, 2016, pp. 85-112).

6 Anna Grzymała-Busse notes that in the post-transition period open conflict with the Catholic Church would have negative consequences for political parties. The more significant political parties are thus more or less clerical, but look for compromise with the Church (Grzymała-Busse, 2019, p. 24).

7 Social trust in the Church decreased 17\% between 2017 and 2020 to a level of 39.5\%, the lowest in history (Przewodnik Katolicki, 2020). The sexual abuse scandal and political engagement of the Church were the main reasons (Boniecki, 2019; Sporniak, 2019).

8 The "Smoleńsk cross" reflects the socio-political divisions since the crash of the plane carrying 96 Polish top officials including President Lech Kaczyński and his wife on 10 April 2010. The delegation was on its way to Katyń in Russia to commemorate the 70th anniversary of the Katyń Massacre in which NKVD forces executed almost 22,000 Polish citizens including some 10,000 Polish officers. The wooden cross installed after the catastrophe by a group of scouts in front of the Presidential Palace has reflected long and emotional disputes on the role of religion and the Catholic Church in the public sphere.

9 See Dobbins, Piotrowska and von Bronk in this volume for a contrasting finding on the openness of Czech political parties.

10 Jan Hus, a main figure Czech history, was a philosopher, theologian and 15th-century religious reformer who anticipated the Lutheran Reformation by a full century. 
He was convicted of heresy at the Council of Constance and burned at the stake in 1415 .

11 In 2008, 27\% of citizens declared their trust in the Churches, while in Poland it was 70\% (Kaczmarek, 2016, p. 249).

12 Interestingly both "fathers" of Czech modern democracy -Tomáš Masaryk in the interwar period and Václav Havel in the post-communist period - referred to the religious dimension in their visions of the Czech state. For Masaryk the religious dimension, which he perceived mainly through the prism of its humanizing values, constituted the inherent element of harmonious existence of the society (Kaczmarek, 2016, p. 119). Václav Havel, while not referring to the religious terminology in the direct way, had deep consideration for "what reaches beyond" (Różańska, 2019, p. 48).

13 The opinion expressed by Jarosław Kaczyński was criticized by the Catholic media in Poland, while pointing out that this is not the view of the Catholic Church itself (Królak, 2019).

14 Caritas Czech Republic is among the biggest organizations of that kind. It is involved in 30 countries and runs 1200 social and health services. It also runs the biggest voluntary aid project in Czech Republic "Three Kings Collection." Its organizations employ over 7,700 employees and have 60,000 volunteers.

15 The number of participants, i.e., parishioners actively involved in the parish organizations, grew from 4\% in 1993 to $8.1 \%$ in 2018 (ibid., p. 33). According to the Main Statistical Office (GUS) in 2018, there were 88.1 registered non-profit entities in Poland. The parish organizations constitute a separate category of non-registered non-profit entities and count 611 of 65.5 non-registered non-profit organizations. All registered organizations counted 8.9 million members at the end of 2018. Compared to 2010 the number of those participating in these organizations decreased by $12.8 \%$ which is about 1.3 million (GUS, 2019, p. 103). Approximately one in five Poles participates in those organizations. On average, the number of members is 30 participants (Stowarzyszenie Klon/Jawor, 2015, pp. 4-9).

16 Church charity activities in Poland are conducted at three levels: diocesan, religious orders and parish organizations. The number of bodies carrying those services was 835 in 2015 . They carried out over five thousand charity projects, mainly with children and youth, the poor, homeless, handicapped, elderly and jobless.

17 In Poland, the state finances social and healthcare insurance contributions of the clergy.

18 Already in 1991, public opinion polls conducted by OBOP showed that $3 / 4$ of respondents wanted a referendum, which was supported with the petition for a referendum in January 1991 collecting 1.3 million signatures (Karolewska, 2018, p. 143). During the heated debate, the Episcopate rejected the proposal of the referendum. The Church argued that ethics issues cannot be resolved this way as "voting on the matter of the legalizing human's life not only violates human rights but it undermines the entire natural order" (Dudek, 2016, p. 172).

19 One politician strongly advocating the total ban on abortion was Sejm marshal Marek Jurek who resigned in 2007 when the ban was not introduced.

\section{References}

Almond, G. A., Powell, G. B., Strøm, K., \& Dalton, R. J. (2000). Comparative Politics Today: A World View. New York: Pearson.

Boniecki, A. (2019). Jeden, święty, powszechny i apostolski. Tygodnik Powszechny 12, 1.

Böckenförde, E., Kaczorowski, P., \& Tischner, J. (1994). Wolność - panistwo - Kościót. Kraków: Znak. 
Cammisa, A., \& Manuel, P. (2016). Religious Groups as Interest Groups. Religions 7(2), 16. doi: $10.3390 / \mathrm{rel} 7020016$

Czech Bishops Conference (2019). The Catholic Church in the Czech Republic. Prague: Czech Bishops Conference.

Dąbrowska, A., \& Szacki, W. (2020). Kim pan jest, panie Gowin? Polityka 18(3259), $19-21$.

Deon (2018). Szkoda, że premier nie przeczytał dokument Episkopatu. Pozostał pielgrzymem PiS. (2018). https://deon.pl/kosciol/szkoda-ze-premier-nie-przeczytaldokument-episkopatu-pozostal-pielgrzymem-pis, 487254 (Accessed 15 May 2020).

Dudek, A. (2016). Historia polityczna Polski 1989-2015. Kraków: Wydawnictwo Znak Horyzont.

Dudová, R. (2010). The Framing of Abortion in the Czech Republic. Czech Sociological Review 46(6), 945-976. doi: 10.13060/00380288.2010.46.6.04

Dylus, A. (2005). Instytucja Kościoła: wspólnota wartości czy grupa interesu?, in: Działania zbiorowe w teorii i praktyce, eds. B. Klimczak, A. Matysiak, Wrocław: Wydawnictwo Akademii Ekonomicznej im. Oskara Langego, 99-101.

Dylus, A. (2019). Z troską o Kościele (ludowym) i o Polsce z nim związanej. Chrześcijaństwo, Świat, Polityka 22, 131-144. doi: 10.21697/csp.2018.22.1.08

Ekiert, G. (2018). Jak traciliśmy złudzenia, Polityka 38(3178), 27-31.

Ekiert, G. (2019). The Dark Side of Civil Society. http://conciliumcivitas.pl/the-dark-sideof-civil-society/ (Accessed 20 August 2020).

Enyedi, Z. (2003). Conclusion: Emerging Issues in the Study of Church-State Relations. West European Politics 26(1), 218-232. doi: 10.1080/01402380412331300277

Episkopat Polski (1991). Radość Życia. List pasterski o miłości małŻeńskiej oraz prawie wszystkich dzieci poczętych do Życia. Warszawa: Episkopat Polski.

Fink, S. (2008). Politics as Usual or Bringing Religion Back in? Comparative Political Studies 41(12), 1631-1656. doi: 10.1177/0010414007309203

Fink, S. (2009). Churches as Societal Veto Players: Religious Influence in Actor-Centred Theories of Policy-Making. West European Politics 32(1), 77-96. doi: 10.1080/01402380802509826

Githens, M. (1996). Reproductive Rights and the Struggle with Change in Eastern Europe, in: Abortion Politics: Public Policy in Cross-Cultural Perspective, eds. M. Githens, D. McBride, New York: Routledge, 55-70.

Główny Urząd Statystyczny (2019). Działalnošć stowarzyszeń $i$ podobnych organizacji społecznych, fundacji, społecznych podmiotów wyznaniowych oraz samorzadu gospodarczego $i$ zawodowego w 2018 r. - wyniki wstępne. Warszawa: Główny Urząd Statystyczny.

Gowin, J. (1995). Kościót po komunizmie, Społeczny Instytut. Kraków: Znak.

Gowin, J. (1999). Kościót w czasach wolności 1989-1999. Kraków: Znak.

Graniszewski, L. (2015). Reprezentowanie interesów grupowych w Polsce. Warszawa: Dom Wydawniczy Elipsa.

Grzymała-Busse, A. (2015). Nations under God. Princeton, NJ: Princeton University Press. Grzymała-Busse, A. (2019). Władza w imię Boże. Polityka 13(3204), 23-25.

Havlíček, T. (2006). Church-State Relations in Czechia. Geojournal 67(4), 331-340. doi: 10.1007/s10708-007-9061-4

Höffner, J. (1992). Chrześcijańska nauka społeczna. Kraków: Wydawnictwo WAM.

ISKK. (2020). Annuarium Statisticum Ecclesiae in Polonia. http://iskk.pl/images/stories/ Instytut/dokumenty/Annuarium_Statisticum_2020_07.01.pdf (Accessed 02 March 2020).

Kaczmarek, H. (2016). Czechy. Kościół i państwo. Kraków: WAM. 
KAI (2018). Raport na 25-lecie. https://ekai.pl/kosciol-w-polsce-raport-na-25-lecie-kai/ (Accessed 15 February 2020).

Karolewska, I. (2018). Aborcja jako przedmiot analizy dyskursu, in: Religia wobec wyzwań wspótczesności z perspektywy nauk społecznych, eds. I. Borowik, S. Grotowska, P. Stawiński, Warszawa: Wydawnictwo Naukowe Scholar, 137-151.

Konferencja Episkopatu Polski (2017). Chrześcijański kształt patriotyzmu. Dokument Konferencji Episkopatu Polski przygotowany przez Radę ds. Społecznych. https://episkopat. pl/chrzescijanski-ksztalt-patriotyzmu-dokument-konferencji-episkopatu-polskiprzygotowany-przez-rade-ds-spolecznych/ (Accessed 20 May 2020).

Konferencja Episkopatu Polski (2018). Rzecznik Episkopatu: aborcja naprawdę nie jest ok, to Życie jest wartościa. https://episkopat.pl/rzecznik-episkopatu-aborcja-naprawde-niejest-ok-to-zycie-jest-wartoscia/ (Accessed 20 July 2020).

Korolczuk, E. (2020). Wieczna wojna. Polityka 46, 26-28.

Kowalczyk, K. (2014). Kościół katolicki jako podmiot oddziałujący na system polityczny. Wrocławskie Studia Politologiczne 17, 126-141.

Kowalczyk, K. (2019). Wpływ prokościelnych grup interesu na ustawodawstwo. Casus regulacji antyaborcyjnych w Sejmie VIII kadencji. Annales Universitatis Mariae CurieSkłodowska, Sectio K-Politologia 26(1), 93. doi: 10.17951/k.2019.26.1.93-106

Kratochvíl, P. (2009). The Religion-Politics Nexus in East-Central Europe: Church in the Public Sphere of Post-Secular Societies. Perspectives 17(2), 119-137.

Królak, T. (2019). Czy poza Kościołem jest tylko nihilizm?. Przewodnik Katolicki, 38, https://www.przewodnik-katolicki.pl/Archiwum/2019/Przewodnik-Katolicki38-2019/Temat-numeru/Czy-poza-Kosciolem-jest-tylko-nihilizm (Accessed 02 March 2020).

Krzemiński, I. (2017). Radio Maryja and Fr. Rydzyk as a Creator of the NationalCatholic Ideology. Religion, in: Religion, Politics, and Values in Poland. Continuity and Change Since 1989, ed by S. P. Ramet \& I. Borowik. Basingstoke: Palgrave Macmillan, 85-112.

Kublik, A., Czuchnowski, W., \& Imielski, R. (2013). KrzyŻ smoleński, https://wyborcza. pl/1,76842,13686085,Krzyz_smolenski.html (Accessed 23 February 2020).

Maćkowiak, T. (2020). Kardynał woli karocę. Polityka 25(3266), 48-49.

Mandes, S. (2020). Clerical Sexual Abuse in an Illiberal State: The Case of Poland. Journal of Church and State 62(1), 110-134. doi: 10.1093/jcs/csz089

Minkenberg, M. (2003). The Policy Impact of Church-State Relations: Family Policy and Abortion in Britain, France, and Germany. West European Politics 26(1), 195-217. doi: 10.1080/01402380412331300267

Modrzejewski, A. \& Raczyński, R. (2019). The Attitude of the Catholic Church in Poland towards Current Migration Crisis. European Journal of Science and Theology 15(6), $1-14$.

O'Mahony, J. (2003). The Catholic Church and Civil Society: Democratic Options in the Post-Communist Czech Republic, in: Church and State in Contemporary Europe. The Chimera of Neutrality, ed. by J. T. S. Madeley, \& Z. Enyedi. London: Frank Cass Publishers, 177-194.

Papieska Rada Iustitia et Pax (2005). Kompendium nauki społecznej Kościoła. Kielce: Jedność.

Potǔček, M. (2000). The Uneasy Birth of Czech Civil Society. Voluntas: International Journal of Voluntary and Nonprofit Organizations 11(2), 107-121. doi: 10.1023/a:1008915807784

Przeciszewski, M. (2020). Potrzebny jest rachunek sumienia Kościoła, 7 November 2020, https://ekai.pl/potrzebny-jest-rachunek-sumienia-kosciola/ (Accessed 22 November 2020). 
Przewodnik Katolicki (2020). Jak odbudować społeczne zaufanie. https://www. przewodnik-katolicki.pl/Archiwum/2020/Przewodnik-Katolicki-7-2020/Wiara-iKosciol/Jak-odbudowac-spoleczne-zaufanie (Accessed 28 February 2020).

Ramet, S. (2014). Religion and Politics in Post-Socialist Central and Southeastern Europe. Basingstoke: Palgrave Macmillan.

Ramet, S. (2017). Sources of the Strength of the Church in Poland: An Introduction, in: Religion, Politics, and Values in Poland. Continuity and Change Since 1989, ed. S. P. Ramet, \& I. Borowik. Basingstoke: Palgrave Macmillan, 1-16.

Różańska, A. (2019). (A)religijność po czesku - ateizm, analfabetyzm religijny czy coś więcej? Edukacja Międzykulturowa 10(1), 38-54. doi: 10.15804/em.2019.01.02

Sowiński, S. (2014). Polityka i religia w Polsce po roku 1989, in: Religia i polityka. Zarys problematyki, eds. P. Burgoński, \& M. Gierycz. Warszawa: Dom Wydawniczy Elipsa, 658-686.

Sporniak, A. (2019). Gniew ludu, gniew Boga. Tygodnik Powszechny 12, 12-16.

Stan, L. \& Turcescu, L. (2011). Church, State and Democracy in the Expanding Europe. New York: Oxford University Press.

Stowarzyszenie Klon/Jawor (2015). Polskie organizacje pozarzadowe 2015. Warszawa: Stowarzyszenie Klon/Jawor.

Strajk Kobiet (2020). http://strajkkobiet.eu/postulaty/ (Accessed 22 November 2020).

Szymczak, W. (2015). Społeczeństwo obywatelskie a religia. Typy relacji w perspektywie wiodących teorii socjologii religii. Roczniki Nauk Społecznych 43(2), 49-75.

Tretera, J. R. \& Horák, Z. (2017). Religion and Law in the Czech Republic. New York: Wolters Kluwer.

Vánĕ, J. (2013). The Relationship between Catholic Church and Civil Society in the Czech Republic. Europolis 7(1), 111-124.

Warner, C. M. (2001). Confessions of an Interest Group: The Catholic Church and the Political Parties in Europe. Princeton, NJ: Princeton University Press.

Wielowieyska, D. (2020). Spór o aborcję to zwierciadło, w którym przeglada się Życie polityczne III RP, https://wyborcza.pl/alehistoria/7,121681,23635739,walka-o-zakaz-aborcjizaczela-sie-w-1989-r-od-tego-czasu.html?cta=1pbox-2hd-3an-5wybory2020 (Accessed 14 July 2020).Zenderowski, R. (2010). Etnicyzacja religii i sakralizacja etnosu: nacjonalizm w Europie Środkowo-Wschodniej. Athenauem 24, 36-49.

Zenderowski, R. (2018). Nowoczesna tożsamość narodowa budowana na zeświecczonej tradycji religijnej (przypadek czeski). Chrześcijaństwo-Świat-Polityka 22, 199-210.

Zuba, K. (2010). The Political Strategies of the Catholic Church in Poland. Religion, State E Society 38(2), 115-134.

Zuba, K. (2020). Not So Much Societal: The Catholic Church in Poland as a Veto Player (forthcoming). 